\title{
Temsilde Adalet ve Yönetimde İstikrar İlkeleri Çerçevesinde Türkiye'de Ülke Seçim Barajı Uygulaması
}

\author{
BATUHAN USTABULUT \\ bustabulut@yahoo.com \\ ORCID ID: 0000-0003-1627-1318
}

Öz: 1982 Anayasasinın 67. maddesine göre seçim kanunlarının "temsilde adalet"ve "yönetimde istikrar" ilkelerini bağdaştıracak şekilde düzenlenmesi gerekmektedir. Bu iki ilke ters yönde işlemektedir. Bu nedenle seçim sistemleri bu ilkelerden birisini öncelemekte, diğer ilkeden ise taviz vermektedir. Bu çalışmada öncelikle ülke seçim barajı uygulaması ile hangi amaçlara ulaşılmak istendiği, bu amaçların hangi ölçüde gerçekleştiği üzerinde durulmuş ve temsilde adalet ve yönetimde istikrar ilkeleri incelenmiştir. Sonrasında 2017 referandumu ile kabul edilen anayasa değişikliğinin seçim sisteminin bu iki işlevine nasıl etki edeceği ve \%10'luk seçim barajının temsilde adaletin sağlanmasına katkı sağlayıp sağlamayacağı sorusuna cevap aranmıştır. Ayrıca çalışma kapsamında 24 Haziran 2018 seçimleri öncesinde kabul edilen seçim ittifaklarının seçim barajı üzerinde nasıl bir etki doğurduğu incelenmiştir. Çalışmada seçim barajı ile ulaşılmak istenen amaçlara büyük ölçüde ulaşılamadığı, temsil adaletinin sağlanamamasının seçmenlerin iradesinin yasama faaliyetlerine yansiması bakımından olumsuz etkileri olduğu ve seçim ittifaklarının ülke seçim barajın fiilen ortadan kaldırma potansiyeline sahip olduğu tespit edilmiştir.

Anahtar kelimeler: Seçim sistemleri, Temsilde adalet, Yönetimde istikrar, Seçim barajı.

\section{Giriş}

Seçim sistemlerinin iki temel işlevi bulunmaktadır. Temsil adaleti ve yönetim istikrarı işlevlerini yerine getirmek üzere tasarlanan seçim sistemleri ters yönde işleyen bu iki ilkeden birisine ağırlık vermek suretiyle siyasî tercih yapmaktadır.

12 Eylül 1980 askerî darbesi sonrasında Türkiye'de siyasetin yeniden dizayn edilmesi ve "yönetimde istikrar"1n sağlanması için \%10'luk ülke seçim barajı getirilmiştir. Ülke seçim barajı uygulaması nedeniyle birçok siyasî parti ve görüş parlamentoda temsil edilebilme imkânı bulamamakta ve bu nedenle seçmenlerin oyu tabir-i caizse çöp sepetine atılmaktadır.

\footnotetext{
* Arş. Gör., Kocaeli Üniversitesi, Hukuk Fakültesi, Anayasa Hukuku Anabilim Dalı.
} 
Bu çalışmada öncelikle seçim hukukuna ilişkin bazı temel kavramlar üzerinde durulacak, sonrasında ise ülke seçim barajı uygulamasının yönetimde istikrarı hangi ölçüde gerçekleştirdiği ve ülke seçim barajı uygulamasının amaçlarına ulaşılıp ulaşılamadığı üzerinde durulacaktır.

Çalışmanın sonunda 16 Nisan 2017 tarihinde yapılan halkoylaması ile kabul edilen ve yönetim istikrarının garanti edileceği söylenen yeni hükümet sisteminde temsil adaletinin sağlanması noktasında ülke seçim barajı uygulaması tartışılacaktır.

\section{Seçim Çevreleri ve Seçim Barajları}

\section{Seçim Çevreleri}

Seçim sistemini ve siyasî partilerin yapısını önemli ölçüde etkileyen seçim çevresi, seçmenlerin oy kullanacakları ve kullandıkları oylarla milletvekillerini belirleyecekleri bölgelerdir. ${ }^{1}$

Seçim çevrelerinin büyüklüğü ifadesi ile kastedilen coğrafî büyüklük ya da seçmen sayısı değil, ilgili çevreden parlamentoya gönderilecek temsilcilerin sayısıdır. ${ }^{2}$ Seçim çevreleri büyüklüklerine göre dar çevre, millî çevre ve geniş çevre şeklinde tasnif edilmektedir. Bir ülkenin milletvekili sayısınca seçim çevresine bölündüğü sistem dar çevre olarak adlandırılmakta olup dar çevre sisteminin uygulandı̆̆ı ülkelerde milletvekili sayısı kadar seçim çevresi bulunmaktadır. Bir ülkenin tek bir seçim çevresi olarak kabul edildiği sistem millî çevre sistemidir. Ülkenin iki ya da daha fazla milletvekili çıkaracak şekilde seçim çevrelerine bölündüğü sistem ise geniş çevre olarak adlandırılmaktadır. ${ }^{3}$ Anayasa koyucu seçim çevrelerine ilişkin herhangi bir tercihte bulunmamış olmakla birlikte Türkiye'de yapılan seçimlerde geniş çevre sistemi uygulanmaktadir. ${ }^{4}$

Seçim çevresi düzeyinde en çok oyu alan siyasî partinin bütün sandalyeleri kazandığ seçim sistemi olan "çoğunluk sistemi", tek isimli seçim çevrelerinde uygulanmaktadır. ${ }^{6}$ Siyasî partilerin seçmenlerden aldıkları oylarla orantılı olarak parlamentodaki sandalyeleri kazanmasını öngören seçim sistemi olan "nisbî (orantılı) temsil sistemi”" ise çok isimli seçim çevrelerini gerekli kılmaktadır. Nisbî temsil sistemlerinin orantılılık derecesinin belirlenmesinde seçim çevrelerinin büyüklüğü önemli bir paya sahiptir. ${ }^{8}$ Bir ülkedeki herhangi bir seçim çevresi ne kadar büyükse seçim çevresi barajı o kadar küçülmektedir. Seçim çevresi barajının küçülmesi oy oranı düşük olan siyasî partilerin barajı geçmelerini kolaylaştıracak ve bu durum daha orantılı seçim sonuçlarının ortaya çıkmasını sağlamaktadır. Seçim çevrelerinin daralması ise

\footnotetext{
1 Bülent Tanör ve Necmi Yüzbaşığlu, 1982 Anayasasına Göre Türk Anayasa Hukuku, 16. bs., İstanbul: Beta Yayınları, 2016, s.228.

2 Ergun Özbudun, "Seçim Sistemleri ve Türkiye”, Ankara Üniversitesi Hukuk Fakültesi Dergisi, 44/I (1995), s.527.

3 Tanör ve Yüzbaşığlu, 1982 Anayasasına Göre Türk Anayasa Hukuku, s.228.

4 Sultan Tahmazoğlu Üzeltürk, “Türk Anayasa Mahkemesi Kararlarında Seçim Sistemleri”, Anayasa Yargısı Dergisi, 23 (2006), s.256.

5 Kemal Gözler, Anayasa Hukukunun Genel Teorisi, Cilt I, Bursa: Ekin Basım Yayın Dağıtım, 2011, s.722.

6 Özbudun, "Seçim Sistemleri ve Türkiye", s.527.

7 Gözler, Anayasa Hukukunun Genel Teorisi, s.726.

8 Özbudun, "Seçim Sistemleri ve Türkiye”, s.527.
} 
aksi yönde sonuçların ortaya çıkmasına neden olmaktadır. Dolayısıyla seçim çevrelerinin daralması ile seçim çevresi barajı yükselecek ve oy oranı daha düşük olan siyasî partilerin seçim çevresi barajını geçmeleri zorlaşmaktadır. Seçim çevrelerinin daralması oy oranı yüksek olan siyasî partiler bakımından büyük bir avantaj sağlamaktadır. Seçim çevresi barajının yükselmesinin doğuracağı en önemli sonuç seçim sonuçlarının daha orantısız olmasıdır. ${ }^{9}$

Seçim çevrelerinin belirlenmesi, seçim hukuku bakımından oldukça önemli bir sorunu teşkil etmektedir. ${ }^{10} 10$ Haziran 1983 tarih ve 2839 sayılı "Milletvekili Seçimi Kanunu"nun 4. maddesinin 1. fikrasında öncelikle her ile bir milletvekili tahsis edileceği hükme bağlanmıştır. Her ile bir milletvekili verildikten sonra kalan milletvekilliklerinin belirlenmesi için nüfusun milletvekili sayısına bölünmesi ile bir sayı elde edilir ve il nüfusunun bu sayıya bölünmesi ile ilin ayrıca çıkaracağı milletvekili sayısı tespit edilmiş olur (m.4/2). İllerin çıkaracağı milletvekili sayısının tespitinde illerin nüfusuna bakılmaksızın öncelikle her ile bir milletvekili tahsis edilmesi uygulaması, nüfusu az olan illeri nüfusu çok olan illere göre daha avantajlı bir konuma getirmektedir. Bu durum dolaylı bir şekilde de olsa büyük partilerin lehine, küçük partilerin aleyhine sonuçlar doğurmaktadır. Nüfusu az olan illerin sandalye sayısı da az olacağından bu iller bakımından seçim çevresi, barajı daha yüksek bir seviyeye çıkarmaktadır. Seçim çevresi barajının yükselmesi oy oranı düşük olan siyasî partilerin barajı aşmalarını güçleştirmektedir. Nüfusuna bakılmaksızın öncelikle her ile bir milletvekili tahsis edilmesi uygulaması, seçim hukuku bakımından temel bir ilke niteliğinde olan "tek kişi, tek oy" prensibine de aykırılık teşkil etmektedir. ${ }^{11}$ Örneğin 1 Kasım 2015 genel seçimlerinde 62.615 seçmenin kayıtlı olduğu Tunceli, Türkiye Büyük Millet Meclisine (TBMM) 2 milletvekili göndermiştir. 3.719 .755 seçmenin kayıtlı olduğu İstanbul 1. Bölgeden ise 31 milletvekili seçmenlerin verdikleri oylarla belirlenmiştir. Buna göre Tunceli'den TBMM’ye gönderilen bir milletvekili yaklaşık 32 bin seçmeni temsil ederken, İstanbul 1. Bölgeden seçilen bir milletvekili ise yaklaşık 120 bin seçmeni temsil etmektedir.

\section{Seçim Barajları}

Seçim barajları siyasî partilerin ve bağımsız adayların parlamentoda temsil edilebilmeleri için aşmaları gereken eşikleri ifade etmekte olup seçim barajlarının, çevre barajı ve ülke barajı şeklinde iki farklı uygulaması söz konusu olmaktadır.

\section{Çevre Barajı}

Seçim çevresi barajında bir siyasî partinin daha önce belirlenmiş bir seçim çevresinden milletvekili çıkarabilmesi ilgili seçim çevresinde kullanılan geçerli oyların belirli bir yüzdesini alması hâlinde söz konusu olmaktadır. ${ }^{12}$ Seçim çevreleri küçüldükçe yükselen seçim çevresi barajı, 1961, 1983 ve 1987 genel seçimlerinde uygulanmış

9 Tanör ve Yüzbaşığlu, 1982 Anayasasına Göre Türk Anayasa Hukuku, s.228; Ergun Özbudun, Türk Anayasa Hukuku, 15. bs., Ankara: Yetkin Yayınları, 2014, s.292.

10 Tahmazoğlu Üzeltürk, “Türk Anayasa Mahkemesi Kararlarında Seçim Sistemleri”, s.255.

11 Özbudun, Türk Anayasa Hukuku, s.292.

12 Hikmet Sami Türk, “Seçim, Seçim Sistemleri ve Anayasal Tercih”, Anayasa Yargısı Dergisi, 23 (2006), s.96. 
olup "basit seçim çevresi barajı” adıyla da anılmaktadır. ${ }^{13}$

1965 genel seçimlerinde uygulanan millî bakiye sistemi ${ }^{14}$ Adalet Partisi'nin tek başına iktidar olmasını engelleme amacıyla tercih edilmiş olsa da bu amaca ulaşılamamıştır. Adalet Partisi'nin mecliste çoğunluğu elde etmesi sonrasında 1968 yılında Milletvekili Seçimi Kanunu'nda yapılan değişiklik sonucu millî bakiye sistemi kaldırılmış ve "seçim çevresi barajlı d'Hondt sistemi”ne geçilmiştir. Milletvekili Seçimi Kanunu’nda yapılan bu değişiklik Anayasa Mahkemesi’ne götürülmüş ve bu değişikliğin iptali istenmiştir. Anayasa Mahkemesi iptal istemine ilişkin yaptığ 1 değerlendirmede seçim çevresi barajını demokratik hukuk devleti ilkesine aykırı bulmuştur. Anayasa Mahkemesi bu kararıyla yönetimde istikrar ilkesine değil, temsilde adalet ilkesine ağırlık vermeyi tercih etmiştir. ${ }^{15}$

1982 Anayasası döneminde kanun koyucu \%10’luk ülke barajına ek olarak basit seçim çevresi barajını tekrar kabul etmiştir. İlk önce seçim çevreleri 7 milletvekili ç1karacak şekilde düzenlenirken daha sonra en çok 6 milletvekili çıkaracak şekilde düzenlenmiş ve bu durum seçim çevresi barajının yükselmesine neden olmuştur. ${ }^{16}$ Görünmeyen bir baraj niteliğinde olan seçim çevrelerinin daraltılması ile artan seçim çevresi barajı ${ }^{17}, 1995$ yılında Milletvekili Seçimi Kanunu’nda yapılan değişiklerle yeniden düzenlenme imkânı bulmuştur. Yapılan bu düzenleme ile seçim çevreleri genişletilmiş ve seçim çevresi barajı düşürülmüştür. ${ }^{18}$ Seçim çevresi barajına ilişkin yapılan bu düzenleme sonrası Anayasa Mahkemesi’nde iptal davası açılmış ve Anayasa Mahkemesi yaptığı değerlendirmede seçim çevresi barajını "partilere aldıkları oy oranında parlamentoda temsil hakkı vermediği, çok küçük farklarla bile kimi partilerin daha çok sayıda milletvekilliği kazanması, bazılarının ise, aldıkları oy oranında bile milletvekili çıkaramaması sonucunu doğuracağı için, Anayasa’nın 67. maddesinin son fikrasındaki "temsilde adalet" ilkesine" aykırı bularak iptal etmiştir. Ayrıca Anayasa Mahkemesi tarafindan yapılan değerlendirmede seçim çevresi barajı oranının ilden ile değişeceği belirtilerek "11 milletvekili çıkaracak bir seçim çevresinde baraj yaklaşı yüzde dokuza, 18 milletvekili çıkaran bir seçim çevresinde yüzde altıya inecektir. Ama dört milletvekili çıkaran bir seçim çevresinde yüzde 25, beş milletvekili çıkaran bir seçim çevresinde yüzde 20 olacaktır” görüşüne yer verilmiş ve bu durum Anayasa Mahkemesi tarafından eşitlik ilkesine aykırı bulunmuştur. ${ }^{19}$

13 Yavuz Sabuncu, "Seçim Barajları ve Siyasal Sonuçları”, Anayasa Yargısı Dergisi, 23 (2006), s.192.

14 "Millî bakiye sistemi", siyasî partilere aldıkları oy oranında mecliste sandalye kazanma imkânı veren ve seçmenler tarafından kullanılan her oyu değerlendiren bir seçim sistemidir. Millî bakiye sistemi temsilde adalet ilkesini esas almakta olduğundan yönetimde istikrarı öngörmemektedir. Millî bakiye sistemi her ne kadar büyük partilere avantaj sağlamıyor ve bu nedenle koalisyon hükümetlerine yol açıyor olsa da bu sistemin uygulandığ 1965 genel seçimlerinde Adalet Partisi tek başına iktidar olmayı başarmıştır. Bkz. Necmi Yüzbaşığlu, “Türkiye’de Uygulanan Seçim Sistemleri ve Bunlara İlişkin Anayasa Mahkemesi Kararlarına Göre Nasıl Bir Seçim Sistemi”, İstanbul Üniversitesi Hukuk Fakültesi Mecmuasl, 55/I-II (1995-1996), s.116-117.

15 Yüzbaşığlu, “Türkiye’de Uygulanan Seçim Sistemleri”, s.116-117.

16 Türk, "Seçim, Seçim Sistemleri ve Anayasal Tercih", s.97.

17 Barış Bahçeci, “1982 Anayasası Döneminde Çoğulcu Demokrasi Açısından Milletvekili Seçimi Hukukunda Karşılaşılan Sorunlar”, Ankara Üniversitesi Hukuk Fakültesi Dergisi, 54 (2005), s.372.

18 Yüzbaşığlu, “Türkiye’de Uygulanan Seçim Sistemleri”, s.135.

19 Anayasa Mahkemesi, 18 Kasim 1995 tarih ve E. 1995/54, K. 1995/59 sayılı Karar, Resmi Gazete, 21 Kasım 1995, Say1 22470. 
İktidar partileri kendilerine avantaj sağlayacağını düşündükleri seçim sistemi değişikliklerini yapmaktan kaçınmamaktadırlar. Örneğin 1987 yılında Anavatan Partisi (ANAP) tarafından yapılan değişiklikle kontenjan adaylı̆̆ı seçim sistemine dâhil edilmiştir. Bu düzenlemeye göre kontenjan adayı gösterilen seçim çevrelerinde en çok oy alan siyasî parti o ildeki kontenjan milletvekilliğini de kazanacaktır. 1987 genel seçimlerinde ANAP \%36,3'lük oy oranına ulaşmış olmasına karşılık TBMM’de \%65'lik bir temsil oranına erişmiştir. ANAP, bir önceki seçimlere göre \%9 oranında daha az oy almış olmasına rağmen ANAP’ın sandalye sayısı $\% 38$ artmıştır. ${ }^{20}$

\section{Ůlke Seçim Barajı}

Ulusal baraj veya genel baraj olarak da adlandırılan ülke barajına göre, "seçim çevrelerinin tümünde geçerli oyların belli bir yüzdesini elde edemeyen partilere belli bir seçim çevresinde ne kadar oy almış olurlarsa olsunlar milletvekilliği verilmez ${ }^{21}$ ". Nisbî temsil sistemlerinde uygulanan ülke barajı ile küçük partilerin parlamento güçlerinin azaltılması amaçlanmaktadır. Diğer siyasî partilere göre oy oranı daha düşük olan siyasî partilerin parlamentodaki güçlerinin ülke barajı uygulaması ile azaltılması amacı sistemde ortaya çıkabilecek istikrarsızlıkları engellemeye hizmet etmektedir. $^{22}$

Siyasî istikrarın sağlanmasını amaçlayan genel baraj, birçok ülke tarafından başvurulan bir uygulama ${ }^{23}$ olmakla beraber genel barajın uygulandığ oranlarda belirlenmiştir. Örneğin Almanya'da ülke baraj1 \%5 olarak belirlenmişken İsveç'te bu oran $\% 4$ 'tür. ${ }^{24}$

Seçim barajı oranlarının hükümet sistemlerine göre tasnif edilmesi oldukça önemlidir. Aşağıda Tablo 1'de parlamenter sistemin uygulandığg 16 ülkedeki, Tablo 2'de yarı başkanlık sisteminin uygulandığ 8 ülkedeki ve Tablo 3'te ise başkanlık sisteminin uygulandığı 6 ülkedeki seçim barajı oranları verilmiştir. ${ }^{25}$

Tablo 1. Parlamenter Sistemin Uygulandı̆̆ı Bazı Ülkelerde Baraj Oranları

\begin{tabular}{|l|c|l|c|}
\hline Ülke & Baraj (\%) & Ülke & Baraj (\%) \\
\hline İngiltere & 0 & Finlandiya & 0 \\
\hline İsviçre & 0 & İrlanda & 0 \\
\hline Hollanda & 0,6 & Danimarka & 2 \\
\hline İspanya & 3 & Yunanistan & 3 \\
\hline Belçika & 3 & İsrail & 3,25 \\
\hline Norveç & 4 & İsveç & 4 \\
\hline
\end{tabular}

20 H. Emre Bağce, “Türkiye'de Siyasi Partiler ve Seçimler: 1946-2015”, Türkiye’de Siyasi Partiler ve Seçim Kampanyaları: Araftaki Seçim - 7 Haziran 2015, haz., Edip Asaf Bekaroğlu, İstanbul: Vadi Yayınları, 2015, s.49. 21 Gözler, Anayasa Hukukunun Genel Teorisi, s.734.

22 Türk, "Seçim, Seçim Sistemleri ve Anayasal Tercih", s.96.

23 Tahmazoğlu Üzeltürk, “Türk Anayasa Mahkemesi Kararlarında Seçim Sistemleri”, s.263.

24 Özbudun, "Seçim Sistemleri ve Türkiye", s.526.

25 Tabloların hazırlanmasında Gözler, Anayasa Hukukunun Genel Teorisi, s. 734 ve Erdoğan Teziç, Anayasa Hukuku, 20. bs., İstanbul: Beta Basım Yayım Dağıtım, 2016, s.372'den yararlanılmıştır. 


\begin{tabular}{|l|l|l|c|}
\hline İtalya & 4 & Çekya & 5 \\
\hline Almanya & 5 & Macaristan & 5 \\
\hline
\end{tabular}

Tablo 1'de yer verilen parlamenter sistemin uygulandığı ülkelerde en yüksek seçim barajının \%5 ile Çekya, Almanya ve Macaristan’da uygulandığı görülmektedir. Bununla birlikte parlamenter demokrasinin beșiği olarak kabul edilen İngiltere'de seçim barajı bulunmamaktadır. Benzer bir şekilde Finlandiya, İsviçre ve İrlanda'da da seçim barajı sıfırdır.

Tablo 2. Yarı Başkanlık Sisteminin Uygulandığı Bazı Ülkelerde Baraj Oranları

\begin{tabular}{|l|c|l|c|}
\hline Ülke & Baraj (\%) & Ülke & Baraj (\%) \\
\hline Fransa & 0 & Portekiz & 0 \\
\hline KKTC & 5 & Romanya & 5 \\
\hline Rusya & 5 & Ukrayna & 5 \\
\hline Gürcistan & 5 & Sirbistan & 5 \\
\hline
\end{tabular}

Tablo 2'de yer verilen yarı başkanlık sisteminin uygulandığı ülkelerde en yüksek seçim barajının \%5 olduğu görülmektedir. Bununla birlikte yarı başkanlık sisteminin ilk olarak uygulandığı Fransa’da seçim barajı bulunmamaktadır. Benzer bir şekilde Portekiz'de de seçim barajı sıfırdır.

Tablo 3. Başkanlık Sisteminin Uygulandığı Bazı Ülkelerde Baraj Oranları

\begin{tabular}{|l|c|l|c|}
\hline Ülke & Baraj (\%) & Ülke & Baraj (\%) \\
\hline ABD & 0 & Güney Kore & 3 \\
\hline Arjantin & 3 & Güney Kibris R.Y. & 3,6 \\
\hline Kazakistan & 7 & Türkiye & 10 \\
\hline
\end{tabular}

Tablo 3'te yer verilen başkanlık sisteminin uygulandığ barajının \%10 ile Türkiyede olduğu görülmektedir. Türkiye, 2017 yılında yapılan hükümet sistemi değişikliği öncesinde de parlamenter sistemin uygulandığı ülkeler arasında en yüksek seçim barajına sahip ülke konumundaydı.

Yukarıda verilen üç tablo hükümet sistemleri ile seçim barajı arasında zorunlu bir birliktelik ilişkisi olmadığını göstermektedir. Yukarıdaki tablolardan da anlaşılabileceği üzere her üç hükümet sisteminin en iyi şekilde uygulandığg ülkeler dikkate alındığında bu ülkelerde seçim barajının olmadığı görülmektedir.

Türkiye'deki ülke seçim barajının diğer ülkelere göre daha yüksek olması "barajın neden \%10 olarak belirlendiği” sorusunun akıllara gelmesine neden olmaktadır. 12 Eylül 1980'de gerçekleştirilen askerî darbe sonrasında oluşturulan ve Anayasa'yı, Siyasî Partiler Kanunu'nu ve Seçim Kanunu’nu hazırlamakla görevlendirilen Kurucu Meclis'in sivil kanadını oluşturan Danışma Meclisi’nin ${ }^{26}$ tutanakları incelendiğinde iki partili bir parlamentonun amaçlandığının Danışma Meclisi üyelerince vurgulandığı görülecektir. Nitekim 1965, 1969 ve 1977 genel seçimlerinde \%10’luk ülke seçim

26 Özbudun, Türk Anayasa Hukuku, s.53. 
barajının uygulanmış olması hâlinde sadece iki partinin meclise gireceği Danışma Meclisi'nin bazı üyeleri tarafından belirtilmiştir. ${ }^{27}$ Örneğin 1977 genel seçimlerinde \%10'dan fazla oy alan yalnız iki parti bulunmakta olmasına ve bu iki partinin oy oranları toplamının \%78’i geçmesine rağmen iki partinin de tek başına hükümeti kurabilecek çoğunluğa ulaşamamış olmasında oy oranı az olan partilerin parlamentoda elde ettikleri temsil gücünün etkisi büyüktür. ${ }^{28} \mathrm{Bu}$ da göstermektedir ki, \%10’luk ülke barajı ile Milliyetçi Hareket Partisi (MHP) ve Millî Selamet Partisi (MSP) gibi partilerin meclise girmeleri engellenmeye çalışılmıştır. Danışma Meclisi üyelerinden Kamer Genç \%10'luk seçim barajının Türkiye’ye yararlı olmayacağını ${ }^{29}$ belirtirken bazı üyeler ise \%10'luk seçim barajını fazla bulmuşlar ${ }^{30}$ ve barajın $\% 8^{31}, \% 7^{32}$ veya $\% 5^{33}$ olarak belirlenmesini teklif etmişlerdir. Bu teklifler Kurucu Meclis tarafından kabul görmemiş ve 10 Haziran 1983 tarihinde kabul edilen 2839 sayılı Milletvekili Seçimi Kanunu’nun 33. maddesi ile ülke barajı $\% 10$ olarak belirlenmiştir.

\section{Ülke Seçim Barajının Amaçları}

Ülke barajı uygulamasının temel amacı oy oranı düşük olan siyasî partilerin mecliste sahip olmaları muhtemel güçlerinin azaltılarak sistemin istikrarını sağlamaktır. ${ }^{34}$ Yavuz Sabuncu'ya göre bu amacın dışında ülke barajı ile ulaşılmak istenen diğer amaçların tamamı yönetimde istikrar ilkesinin hayata geçirilmesi ile ilişkilidir. ${ }^{35}$ Ülke barajı uygulaması ile ulaşılmak istenen amaçlar aşağıda sıralanmış ve bu amaçlara hangi ölçüde ulaşıldığı tartışılmıştır:

- Yukarıda da ifade edildiği üzere ülke barajı uygulamasının ana amacı hükümet istikrarının sağlanmasıdır. Tek bir partinin meclisin çoğunluğuna sahip olduğu ve böylelikle uzun süre boyunca görevde kalabilecek istikrarlı hükümetlerin ülkenin yönetimini yürütebilmesini sağlamayı amaçlayan ${ }^{36}$ ülke barajı ile hedeflenen istikrara ulaşılıp ulaşılamadığı, ulaşıldı ise bunun hangi ölçüde gerçekleştiği tartışmaya açıtır. ${ }^{37}$ 1983, 1987, 2002, 2007 genel seçimleri ve 1 Kasım 2015 genel seçimi haricindeki seçimlerin sonucunda Türkiye koalisyon hükümetleri ile yönetilmiştir. Bu durum ülke seçim barajı uygulamasının bu amacı gerçekleştirmede başarılı olamadığını göstermektedir.

- Ülke barajı uygulamasının bir diğer amacı meclisteki parti sayısının sınırlandırılmasıdır. Bu amaç mecliste parçalı bir siyasî yapının oluşmasını engellemeye yöneliktir. $^{38}$ Türkiye’de ülke barajının uygulandığ

27 Danışma Meclisi Tutanak Dergisi, C.17, 25.4.1983 tarihli oturum, s.20.

28 Barış Bahçeci, “Milletvekili Seçimi Hukukunda Karşılaşılan Sorunlar”, s.371.

29 Danışma Meclisi Tutanak Dergisi, C.17, 25.4.1983 tarihli oturum, s.27.

30 Danışma Meclisi Tutanak Dergisi, C.17, 25.4.1983 tarihli oturum, s.54, 61, 64.

31 Danışma Meclisi Tutanak Dergisi, C.17, 25.4.1983 tarihli oturum, s.61.

32 Danışma Meclisi Tutanak Dergisi, C.17, 4.5.1983 tarihli oturum, s.278.

33 Kamer Genç tarafından verilen değişiklik teklifi için bkz. Danışma Meclisi Tutanak Dergisi, C.17, 4.5.1983 tarihli oturum, s.278.

34 Türk, "Seçim, Seçim Sistemleri ve Anayasal Tercih", s.96.

35 Sabuncu, "Seçim Barajları ve Siyasal Sonuçları”, s.193.

36 Sabuncu, "Seçim Barajları ve Siyasal Sonuçları”, s.193.

37 Bahçeci, "Milletvekili Seçimi Hukukunda Karşılaşılan Sorunlar", s.373.

38 Sabuncu, "Seçim Barajları ve Siyasal Sonuçları”, s.193. 
1987 ve 2002 tarihlerinde yapılan seçimlerde bu amaca ulaşılmıştır. Ancak 1987 genel seçimlerinde 4.6 milyon seçmenin oyu tercih ettikleri siyasî partilerin ülke barajını aşamamaları nedeniyle meclise yansımamış, değerlendirme dışı kalmıştır. 2002 genel seçimleri sonucunda değerlendirme dışı kalan seçmen oyu ise 14 milyondur. ${ }^{39}$

- Ülke barajı uygulaması ile ulaşılmak istenen amaçlar arasında çok sayıda siyasî partinin kurulmasını ve çok sayıda siyasî partinin seçimlere girebilmesini engellemek de bulunmaktadır. ${ }^{40}$ Fakat ülkemizde \%10'luk ülke seçim barajının uygulandığ 1 seçimlerde parti sayısının azalmadığı ve hatta arttığı gözlemlenmiştir. Dolayısıyla ülke barajı ile ulaşılmak istenen parti sayısının azaltılması amacına ulaşılamadığı görülmüştür. ${ }^{41}$ Nitekim Yargıtay Cumhuriyet Başsavcılığı’nın faaliyette olan siyasî partilere ilişkin 22 Mart 2018 tarihinde yayınladı̆̆ 1 verilere göre Türkiyede 86 siyasî parti faaliyet göstermektedir. ${ }^{42}$ Halbuki Danışma Meclisi’nin 23 Ekim 1981 günlü 1. Birleşiminde Devlet Başkanı sıfatıyla Kenan Evren tarafından “parti enflasyonu”nu önleyecek bir seçim sisteminin millet tarafından beklendiği vurgulanmıştır. ${ }^{43}$ Türkiye'de faaliyette olan siyasî partilerin sayısının bu denli yüksek olması Kenan Evren tarafından ifade edilen parti enflasyonunun ülke seçim barajı uygulamasına rağmen devam ettiğinin göstergesidir.

Ülke barajının olmadığı 1961 Anayasası döneminde seçimlere katılan partilerin sayısı en fazla 9 olmasına karşın, 1983'te ${ }^{44}$ bu sayı 3, 1987'de 7, 1991'de ise 6'dır. 1995 genel seçimlerinden itibaren seçime giren partilerin sayısında artış gözlemlenmiştir. 1995 genel seçimlerine katılan parti sayısı 12, 1999 genel seçimlerine katılan parti sayısı 20, 2002 genel seçimlerine katılan parti sayısı ise 18 olmuştur. ${ }^{45} \mathrm{Bu}$ da göstermektedir ki, ülke barajı ile seçime giren parti sayısının azaltılması amacına ulaşılamamıştır.

- \%10 ülke barajı ile ulaşılmak istenen amaçlar arasında bölgesel partilerin oluşumunu önlemek, bölgesel partilerin oluşması hâlinde ise bu partilerin meclise girmelerini engellemek gibi bir hedef de bulunmaktadır. ${ }^{46}$ Ülke seçim barajı uygulaması etnik/ bölgesel kökene dayanan siyasî partilerin kurulmasını önleyememiş olsa da bu partilerin ülke barajını geçerek mecliste temsil edilmelerini büyük ölçüde engellemiştir. ${ }^{47}$ Ülke barajına takılarak meclise giremeyen etnik/bölgesel partiler, seçim ittifakları ya da bağımsız adaylar göstermek suretiyle meclise girmeye çalışmışlardır. 1991 yılında Halkın Emek Partisi (HEP), Sosyaldemokrat Halkçı Parti (SHP) ile seçim ittifakı yapmış ve SHP listesinden seçime giren 18 HEP’li, milletvekili seçilmiştir. 1995 ve 1999 genel seçimlerinde Halkın Demokrasi Partisi (HADEP), 2002 genel seçimle-

39 Sabuncu, "Seçim Barajları ve Siyasal Sonuçları", s.194.

40 Sabuncu, "Seçim Barajları ve Siyasal Sonuçları", s.193.

41 Bahçeci, "Milletvekili Seçimi Hukukunda Karşılaşılan Sorunlar”, s.384.

42 "Faaliyette Olan Siyasi Partiler", Yargıtay Cumhuriyet Başsavcılı̆̆ı, erişim 1 Nisan, 2018, https://www. yargitaycb.gov.tr/sayfa/faaliyette-olan-siyasi-partiler/documents/SPartiler22032018.pdf.

43 Danışma Meclisi Tutanak Dergisi, C.1, 23.10.1981 tarihli oturum, s.5.

44 Millî Güvenlik Konseyi, 1983 yılında gerçekleştirilen genel seçimlere sadece 3 partinin katılmasına izin vermiştir.

45 Sabuncu, "Seçim Barajları ve Siyasal Sonuçları", s.194.

46 Sabuncu, "Seçim Barajları ve Siyasal Sonuçları”, s.193.

47 Sabuncu, "Seçim Barajları ve Siyasal Sonuçları”, s.195. 
rinde ise Demokratik Halk Partisi (DEHAP) ülke barajını aşamayarak milletvekili çıkaramamışlardır. 2007 genel seçimlerinde Demokratik Toplum Partisi (DTP) ve 2011 genel seçimlerinde ise Barış ve Demokrasi Partisi (BDP), parti kurumsal kimliği ile seçime girmek yerine bağımsız aday göstermek suretiyle seçime katılmışlar ve birçok ilden milletvekili çıkarmayı başarmışlardır. DTP ve BDP destekli bağımsız adaylar daha sonra partilerine dönmüşler ve partilerinin meclis grubu kurmalarını sağlamışlardır.

\%10 ülke seçim barajının uygulandığ 1 seçimlerde mağduriyet yaşayan tek siyasî hareketin HEP-HADEP-DEHAP-DTP-BDP olduğunu söyleyebilmek mümkün değildir. Nitekim 1995 genel seçimlerinde Milliyetçi Hareket Partisi (MHP), \%8.18 gibi bir oy almasına rağmen barajı geçememiş ve bu nedenle meclis dışında kalmıştır. Burak Oder'e göre HADEP ve MHP, etnik politikaları öncelemeleri nedeniyle ortak bir yöne sahiptirler ve ülke barajı bu iki partinin elenmesine neden olmaktadır. Bu nedenle ülke barajının yönetimde istikrar ilkesinin hayata geçirilmesinden ziyade siyasî bir elemeye hizmet ettiğini söylemek yanlış olmayacaktır. ${ }^{48}$

7 Haziran ve 1 Kasım 2015 tarihlerinde yapılan her iki genel seçimde ise parti kurumsal kimliği ile seçime giren Halkların Demokratik Partisi (HDP) ülke barajını aşarak mecliste temsil edilebilme imkânına erişmiştir. 7 Haziran ve 1 Kasım 2015 genel seçimlerinin sonuçları göz önüne alındığında ülke barajı uygulamasının bölgesel yoğunluğa sahip partiler bakımından doğurduğu olumsuz sonuçların ortadan kalktığı dikkat çekmektedir. Bu nedenle ülke barajı uygulamasının bu açıdan beklentileri karşılamadığı yorumunda bulunmak yanlış olmayacaktır.

- Ülke barajı uygulaması ile seçmenlerin oylarının ziyan olmaması için büyük partilere (tercihen iki büyük partiye) yönlendirilmesi de amaçlanmaktadır. ${ }^{49}$ Seçmenler, \%10'luk seçim barajının yüksek olmasından dolayı oy kullanırken ilk tercihleri olan siyasî partilerin baraj altı kalması ihtimaline karşı diğer siyasî partilerden birisini tercih etmektedirler. Bu nedenle ülke barajı uygulaması, "samimi oy kullanmak yerine, stratejik oy kullanma"yı teşvik etmektedir. ${ }^{50}$ Stratejik oy kullanımı, millî iradenin parlamentoya tam olarak yansımasını engellemektedir. Seçmenler birinci tercihlerine oy verdiklerinde oylarının ziyan olacağını düşündüklerinden genellikle ikinci tercihlerine yönelmekte ve bu durum, aslında aynı görüşü paylaştıkları partinin birçok görüşünün mecliste dile getirilmesini engellemektedir. Nitekim TÜSİAD tarafından yapılan bir araştırmada, "Küçük partilerin barajı aşamayacağı bilindiği için, büyük partiler küçük partilerin seçmenlerinin taleplerini ciddiye almıyor. Böylece toplumun bir bölümü Meclis’te temsil edilemiyor” eleştirisinin haklı olup olmadığı sorusu deneklere yönetilmiş ve deneklerin \%80,5’i bu eleştirinin haklı olduğu görüşünü ifade etmiştir. ${ }^{51}$

48 Burak Oder, “1983’ten Bu Yana Seçim Sisteminde Yaşanan Değişiklikler ve 24 Aralık 1995 Seçimi Sonuçlarının Çeşitli Varsayımlarla Değerlendirilmesi”, İstanbul Üniversitesi Hukuk Fakültesi Mecmuası, 55/IV (1997), s.107. 49 Sabuncu, "Seçim Barajları ve Siyasal Sonuçları”, s.193.

50 Seyfettin Gürsel, “Türkiye İçin Yeni Seçim Sistemi Önerisi”, Rapor, İstanbul: Bahçeşehir Üniversitesi Ekonomik ve Toplumsal Araştırmalar Merkezi, Ocak 2013, s.7.

51 Seçim Sistemi ve Siyasî Partiler Araştırması, Cilt II, Ana Rapor, TÜSİAD, İstanbul, 2001, s.87. 
- Seçmeni merkeze teşvik etmek, ülke barajı ile ulaşılmak istenen bir diğer amaç olarak gösterilebilir. ${ }^{52} \mathrm{Bu}$ amacın ne kadar gerçekleştiği de tartışmaya açıktır. Merkez sağın temsilcileri olan Doğru Yol Partisi (DYP) ile ANAP’ın, Demokrat Parti çatısı altında birleşmek için yoğun çaba harcaması, bu birleşmenin büyük güçlükler sonrasında gerçekleşmesine rağmen merkez sağın 2011 seçimlerinde oy oranının çok düşük bir seviyede kalmış olması göz önüne alındığında bu amaca ulaşılabildiğini söyleyebilmek de güçleşmektedir.

Yukarıda yapılan açıklamalardan da anlaşılabileceği üzere ülke seçim barajı ile ulaşılmak istenen amaçlara sınırlı ölçüde ulaşılabildiği söylenebilir. ${ }^{53} \% 10$ barajından umulan faydaların azalmasında 12 Eylül yönetimince, 12 Eylül askerî darbesinden önce faaliyet gösteren bütün partilerin kapatılması, siyasetten yasaklanmış olan liderlerin yasaklarının kaldırılması suretiyle siyasete dönmelerine imkân sağlanması ve 12 Eylül yönetimince kapatılmış olan siyasî partilerin yeniden kurulması ve büyük partilerin oy oranlarının azalmasının etkili olduğu söylenebilir. ${ }^{54}$

Sabuncu'ya göre seçim barajı siyasî hayata iki tür etki yapmıştır. Seçim barajının siyasî hayata yaptığı ilk etki ülke barajı uygulamasının doğurduğu kurumsal sonuçlardır. Ülke barajı uygulamasının doğurduğu kurumsal sonuçlar kısa vadede sandalye dağ1lımı üzerinde kendisini gösterirken orta-uzun vadede ise siyasî partinin yaşamında kendisini göstermektedir. ${ }^{55} 2002$ yılında yapılan genel seçimlerde DYP’nin \%9,54'lük oy oranına sahip olmasına karşılık ülke barajını geçememesi nedeniyle meclise girememesi sonucunda DYP'nin birçok seçim çevresinde kazandığı sandalyeler barajı geçen iki partiye dağıtılmıştır. Bu durum ülke barajı uygulamasının kısa vadeli kurumsal sonuçlarına örnek olarak gösterilebilir. Ayrıca DYP’nin 2007 genel seçimlerinde Demokrat Parti kurumsal kimliği ile \%5,42 oranında, 2011 genel seçimlerinde \%0,65 oranında, 7 Haziran 2015'te \%0,16 ve 1 Kasım 2015 genel seçimlerinde ise $\% 0,14$ oranında oy almış olması ise ülke seçim barajı uygulamasının orta-uzun vadeli sonuçları bakımından örneklik teşkil etmektedir.

Seçim barajının siyasî hayata yaptığg ikinci tür etki ise ülke barajı uygulamasının doğurduğu davranışsal sonuçlarda görülmektedir. Ülke barajı uygulaması, seçmenlerin oy kullanma davranışlarında uzun vadeli değişimlere neden olabilmektedir. Ülke barajı uygulamasının uzun vadeli etkilerini ortaya koyabilmek barajın kurumsal sonuçlarına ilişkin değerlendirmede bulunmaktan daha zordur. ${ }^{56}$

\section{Temsilde Adalet ve Yönetimde İstikrar İlkeleri Çerçevesinde Yeni Hükümet Sisteminde Ülke Seçim Barajı}

\section{Temsilde Adalet ve Yönetimde İstikrar İlkeleri}

Dar anlamda "seçmenlerce verilen oyların parlâmento sandalyelerine dönüştürülmesinde uygulanan kurallar" 57 olarak tanımlanan seçim sisteminin iki temel işlevi

52 Sabuncu, "Seçim Barajları ve Siyasal Sonuçları", s.193.

53 Sabuncu, "Seçim Barajları ve Siyasal Sonuçları", s.195.

54 Bahçeci, "Milletvekili Seçimi Hukukunda Karşılaşılan Sorunlar”, s.386.

55 Sabuncu, "Seçim Barajları ve Siyasal Sonuçları”, s.192.

56 Sabuncu, "Seçim Barajları ve Siyasal Sonuçları", s.192.

57 Özbudun, Türk Anayasa Hukuku, s.282. 
bulunmaktadır. Seçim sisteminin ilk temel işlevi, yapılan seçimler sonucunda mecliste bir çoğunluğun oluşmasının sağlanması ve bunun sonucunda hükümetin belirlenmesine imkân verilmesidir. Seçim sisteminin bu işlevine "yönetimde istikrar ilkesi” adı verilmektedir. Seçim sisteminin ikinci temel işlevi ise halk içindeki farklı görüşlerin meclise yansımasını sağlamaktır. Halkın çoğulcu bir biçimde katılımını sağlayan bu ilkeye "demokratik temsil" ya da "temsilde adalet ilkesi" adı verilmektedir. $^{58}$

Temsilde adalet ilkesi, çok partili siyasî yaşama ve dolayısıyla çok sesliliğe uygun düşmekte olduğundan oldukça önemli bir ilkedir. Bu özellikleri nedeniyle temsilde adalet ilkesinin, bir seçim sistemi bakımından vazgeçilmez bir nitelikte olduğu söylenebilir. Türkiye dâhil olmak üzere bütün ülkelerin ihtiyacı olan yönetimde istikrar ilkesi, Anayasa Mahkemesi tarafından seçmenlerin kullandıkları oyların yasama organına, yürütme organının güçlü olmasını sağlayacak şekilde yansıması olarak algılanmaktadir. ${ }^{59}$

“Temsilde adalet" ile "yönetimde istikrar", yukarıda ifade edildiği üzere ters yönde işleyen iki ilke olup her ülke kendi siyasî özelliklerine uygun düşecek şekilde bu iki ilkeyi bir araya getirmek istemektedir. ${ }^{60}$ Temsilde adalet ile yönetimde istikrar ilkelerinden birine öncelik ve ağırlık verildiğinde diğer ilke zarar görmektedir. Bunun anlamı temsil adaletini sağlamayı amaçlayan bir seçim sisteminde istikrar ilkesinden taviz verilmesi, istikrarın sağlanmaya çalışıldığı bir seçim sisteminde ise adalet ilkesinden taviz verilmesinin gerektiğidir. Ergun Özbudun, bu iki ilkenin hangisinden taviz verileceğinin ülkeden ülkeye ve dönemden döneme değișen bir siyasî tercih olduğunu vurgulamış ve "iki ilkeyi bağdaştırmaktan değil, iki ilkeden de belli ölçülerde ödün vererek ortalama bir yol bulmaktan söz etmek” gerektiğini belirtmiştir. Ayrıca Özbudun'a göre, temsilde adalet ve yönetimde istikrar ilkelerinin hangisinden ne ölçüde taviz verileceğinin bilimsel olarak belirlenebilmesi mümkün değildir. ${ }^{61} \mathrm{Bu}$ kapsamda siyasî partilerin aday belirlemelerinin merkezden yapılmasının sınırlandırılması, aday belirlemede parti üyelerinin katılımının sağlanması, tercihli oy sisteminin hayata geçirilmesi ve ön seçimin kabul edilmesi gibi ilkeler temsilde adalete ve buna bağlı olarak yönetimde istikrara orta ve uzun vadede daha fazla hizmet edebilir. ${ }^{62}$

Anayasa'nın 67. maddesine 1995 yılında eklenen 6. fikra ile "Seçim kanunları, temsilde adalet ve yönetimde istikrar ilkelerini bağdaştıracak biçimde düzenlenir" kuralı kabul edilmiştir. Bu fikra hükmünün kabul edilmesi ile "temsilde adalet" ve "yönetimde istikrar” ilkeleri anayasal bir değere kavuşturulmuş ve birer pozitif hukuk kuralı hâline getirilmiştir.

58 Türk, "Seçim, Seçim Sistemleri ve Anayasal Tercih", s. 77-78; Yüzbaşığlu, “Türkiyedde Uygulanan Seçim Sistemleri”, s.105.

59 Nihat Bulut, “Temsilde Adalet - Yönetimde İstikrar İkilemi Bağlamında 12 Haziran 2011 Seçimleri”, Erzincan Üniversitesi Hukuk Fakültesi Dergisi, 14/III-IV (2010), s.3.

60 Türk, "Seçim, Seçim Sistemleri ve Anayasal Tercih", s.78.

61 Özbudun, "Seçim Sistemleri ve Türkiye", s.533.

62 Bedrettin Kesgin, Siyaset Bilimi ve Kamu Yönetimi, İstanbul: Açılım Yayınları, 2014, s.129. 
1995 yılında yapılan değişikliklerle temsilde adalet ve yönetimde istikrar ilkelerinin anayasaya dâhil edilmesi sonrasında seçim sistemi tercihinin tümüyle TBMM'ye b1rakılmış olduğunu söyleyebilmek mümkün gözükmemektedir. ${ }^{63} \mathrm{Bu}$ iki ilkenin anayasal değere kavuşturulması ve seçim kanunlarının bu iki ilkeyi bağdaştıracak şekilde düzenlenmesi gerektiği kuralının benimsenmesi seçim kanunlarının Anayasaya aykırılığı sorununa yeni bir boyut kazandırmıştır. ${ }^{64}$ Nitekim 1995 yılında yapılan söz konusu anayasa değişikliği sonrasında Anayasa Mahkemesi tarafından verilen kararlarda temsilde adalet ve yönetimde istikrar ilkeleri birer temel ölçü norm olarak kullanılmıştır. ${ }^{65}$

\section{Yeni Hükümet Sisteminde Ülke Seçim Barajı}

16 Nisan 2017 tarihinde yapılan halkoylaması ile kabul edilen anayasa değișikliği, hükümet sistemine ilişkin önemli değişiklikleri ihtiva etmektedir. Anayasa değişikliğine ilişkin kanun teklifinin genel gerekçesinde yer verilen “(ö)zü itibarıyla 1961'de oluşturulan hükümet sisteminin Türkiye’de bir türlü istikrar üretemediği” ve "yürürlükteki anayasaların tercih ettiği hükümet sistemleri(nin), beklenen kamusal faydayı istenen düzeyde sağlayamamış, istikrarsızlıkların, krizlerin ve vesayetlerin önünde mutlak bir güvence oluşturamamış ${ }^{60 "}$ olduğu fikrinin hükümet sisteminde değişikliğe neden olan temel faktör olduğu söylenebilir. Ayrıca anayasa değişikliğine ilişkin kanunun genel gerekçesinde "(ü)lkemizdeki siyasi hayatın istikrara kavuşturulması ve tartışmasız istikrar üreten bir sistemin benimsenmesinin önemi ${ }^{67 \text { ” }}$ üzerinde durularak yeni hükümet sisteminin bu amacı sağlayacağı vurgulanmıştır.

Anayasa koyucu, “Türkiye Büyük Millet Meclisinin 27’nci Yasama Dönemi milletvekili genel seçimi ve Cumhurbaşkanlığı seçimi 3/11/2019 tarihinde birlikte yapılır. Seçimin yapılacağ 1 tarihe kadar Türkiye Büyük Millet Meclisi üyeleri ve Cumhurbaşkanının görevi devam eder. Meclisin seçim kararı alması halinde 27 nci Yasama Dönemi milletvekili genel seçimi ve Cumhurbaşkanlığı seçimi birlikte yapılır." (Geçici Madde 21/A) hükmüne yer vermiştir. Bu hükmün anlamı yeni hükümet sisteminin 27. Yasama Dönemi için yapılacak milletvekili genel seçimi ve Cumhurbaşkanlığ seçimi ile yürürlüğe girecek olmasıdır.

Anayasa değişikliğine ilişkin kanunun genel gerekçesinde "yeni hükümet sisteminin tartışmasız bir şekilde istikrar üreteceği” belirtilmiştir. Hükümet istikrarının seçmenlerin kullanacakları oylarla garanti edileceğinin belirtildiği yeni hükümet sistemi, kendisiyle uyumlu bir milletvekili seçim kanununa ihtiyaç duymaktadır.

Yeni hükümet sistemiyle uyumlu bir milletvekili seçim kanununun, çok partili siyasî hayata geçilmesini sağlayan 1946 genel seçimlerinden bugüne oluşan yaklaşık 71 yıllık tecrübeyi göz ardı edebilmesi mümkün gözükmemektedir. Bu nedenle Yüz-

63 Yüzbaşığlu, “Türkiye’de Uygulanan Seçim Sistemleri”, s.148.

64 Bahçeci, “Milletvekili Seçimi Hukukunda Karşılaşılan Sorunlar”, s.373.

65 Yüzbaşığlu, “Türkiye’de Uygulanan Seçim Sistemleri”, s.148.

66 “TBMM Anayasa Komisyonu Raporu”, Türkiye Büyük Millet Meclisi, erişim 1 Nisan 2018, https://anayasa. tbmm.gov.tr/docs/1982/1982-19/19-sirasayisi.pdf, s.11.

67 “TBMM Anayasa Komisyonu Raporu”, s.11. 
başıŏlu, "yeni ve bilinmeyen maceralara atılmak yerine, (...) bu birikimi değerlendirmek ve mevcut seçim sisteminin aksaklıklarını düzeltmek daha doğru ve akılcı olacaktır" fikrini savunmaktadır. ${ }^{68}$ Türkiye'de göç sorununun ve bazı bölgelerde hâlâ güçlü olan feodal yapının varlığını devam ettirdiği düşünüldüğünde dar bölgelerin oluşturulmasının güç olduğu görülecektir. Bu nedenle çoğunluk sisteminin kanun koyucu tarafından tercih edilmesi temsil adaletinin sağlanmasını engelleyecektir. ${ }^{69}$ Bu görüşten hareketle nisbî (orantılı) temsil seçim sisteminin uygulanmasının daha sağlıklı sonuçlar doğuracağının vurgulanması gerekmektedir.

Yeni hükümet sisteminin yürürlüğe girmesi ile seçim sisteminin iki temel işlevinden biri olan "yönetimde istikrar ilkesi”nin garanti edileceği vurgusu göz önüne alınd1ğında milletvekili seçimi kanununun "temsilde adalet ilkesi”ni öncelemesi kaçınılmaz hâle gelmiş bulunmaktadır. Yönetimde istikrar ile temsilde adalet ilkelerinin ters yönde işlemeleri ve bu iki ilkeden birisine ağırlık verildiğinde diğerinden taviz verilmesi gerektiği düşünüldüğünde, yeni hükümet sisteminin istikrarı garanti edeceği söylenen fonksiyonu karşısında temsil adaletinin nasıl sağlanacağ bir sorun olarak ortaya çıkmaktadır. Bu nedenle yeni hükümet sistemiyle uyum sağlayacak yeni milletvekili seçim kanunu bakımından temel tartışma konularının başında yukarıda üzerinde durulan ülke seçim barajı uygulaması gelmektedir.

Sadece ülke seçim barajı oranının düşürülmesi hâlinde mevcut aksaklıkların bir kısmının giderebilmesine imkân verilmiş olacaktır. Ülke seçim barajında yapılacak görece iyileştirme ortaya çıkması muhtemel yeni sorunlara da yol açabilme potansiyeline sahip bulunmaktadır. ${ }^{70}$ Ülke seçim barajının \%10 ya da küçük bir iyileştirmeyle biraz daha düşük bir oran ile korunduğu bir seçim sisteminin yürütülmeye devam edilmesi hâlinde 3 Kasım 2002 genel seçimleri sonucunda yaşanan ve seçmenlerin \%45'inin temsil edilemediği bir parlamentonun oluşmaması için herhangi bir garanti söz konusu değildir. ${ }^{71}$

Temsilde adaletin tam anlamıyla gerçekleşmesi ancak sıfır barajlı bir seçim sistemi ile söz konusu olabilecektir. Ülke seçim barajının sıfırlanması fikrine çok parçalı bir parlamento aritmetiğinin söz konusu olabileceği söylenerek karşı çıkılabilir. Mevcut sistemde \%10'luk yüksek seçim barajının özellikle 90’lı yıllar boyunca çok parçalı bir parlamentonun oluşmasını engellemediği göz önüne alındığında ülke seçim barajı uygulamasının sürdürülmesi hâlinde de aynı tehlike söz konusu olabilecektir. Ayrıca Cumhurbaşkanlığı seçiminin ilk turunda herhangi bir adayın salt çoğunluğa ulaşamaması hâlinde seçim ikinci tura kalacak ve ikinci turda adaylar diğer siyasî partilerin desteğini almaya çalışacaklardır. Bu durumda karşılıklı verilecek tavizlerle bir uzlaşma zemini aranacaktır. Barajın sıfırlandığı bir seçim sisteminde parlamentoda farklı siyasî partilerin temsil edilmesi ve herhangi bir siyasî partinin tek başına çoğunluğa ulaşamaması durumunda da çıkarılmak istenen kanunlara ilişkin uzlaşı arayışlarına girilecektir.

68 Yüzbaşığlu, “Türkiye’de Uygulanan Seçim Sistemleri”, s.144. 69 Yüzbaşıŏlu, “Türkiye'de Uygulanan Seçim Sistemleri”, s.146.

70 Gürsel, "Türkiye İçin Yeni Seçim Sistemi Önerisi”, s.9.

71 Gürsel, “Türkiye İçin Yeni Seçim Sistemi Önerisi”, s.4. 
Cumhurbaşkanlığına kimlerin aday gösterebileceğini düzenleyen Anayasa’nın 101. maddesinin 3. fıkrasında yapılan değişiklikten hareketle ülke seçim barajının \%5’e indirilmesi görüşü ileri sürülmektedir. Anayasa’nın 101. maddesinin 3. fikrasında "Cumhurbaşkanlığına, siyasi parti grupları, en son yapılan genel seçimlerde toplam geçerli oyların tek başına veya birlikte en az yüzde beşini almış olan siyasi partiler ile en az yüz bin seçmen aday gösterebilir.” hükmüne yer vermiş olduğundan ülke seçim barajının \%5'e indirilmesi gerektiği teklif edilmektedir. Fakat anayasa koyucunun siyasî partilerin Cumhurbaşkanı adayı gösterebilmesi için tek başına veya birlikte en az $\% 5$ oy almış olma şartını koymuş olmasından parlamentoda temsil açısından bir sonuç çıkarabilmek mümkün gözükmemektedir. Çünkü yeni hükümet sisteminin esas aldığ de ayrılıyor olması yasama organında temsil edilebilmenin yürütme organına aday gösterebilme ile orantılı olması sonucuna ulaşmayı engellemektedir. Ayrıca Gürsel’e göre “(b)arajin yüzde 5’e düşürülmesini talep etmek temsil adaleti açısından işlevsiz ve anlamsız"72 olacaktır. Bu nedenle barajı olmazsa olmaz görenler bakımından ülke seçim barajının \%5’e düşürülmesi yerine \%3’e düşürülmesi yönündeki tekliflere kulak verilmesi daha doğrudur. Çünkü siyasî partilerin devlet yardımından yararlanabilmeleri kanun koyucu tarafından, yapılan son genel seçimlerde $\% 3$ oy almalarına bağlanmıştır.

Ülke seçim barajının tamamen kaldırılması yönündeki tekliflerin hayata geçirilmesi her ne kadar gerçekçi görünmüyor olsa da kanun koyucunun çok hızlı bir şekilde çok önemli değişiklikleri hayata geçirebildiği göz önüne alındığında ülke seçim barajının sıfırlanabilmesinin her zaman ihtimal dâhilinde olduğu söylenebilir.

\section{Seçim İttifaklarının Ülke Seçim Barajına Etkisi}

26 Nisan 1961 tarih ve 298 sayılı Seçimlerin Temel Hükümleri ve Seçmen Kütükleri Hakkında Kanun ve 10 Haziran 1983 tarih ve 2839 sayılı Milletvekili Seçimi Kanununda 13 Mart 2018 tarihinde yapılan değişikliklerle siyasî partilerin ittifak yapabilmelerine imkân tanınmıştır. Milletvekili Seçimi Kanununun 12. maddesine seçim ittifakı ile ilgili düzenlemeler eklenmiştir. Yapılan bu değişikliklerle siyasî partilerin bir protokol çerçevesinde ittifak yapmak suretiyle seçimlere katılabilmeleri mümkün hâle getirilmiştir. Kanunun 26. maddesine eklenen paragrafa göre ittifak yapan siyasî partiler oy pusulasinda yan yana yer almakta ve ittifak yapan partilerin siraları kura ile belirlenmektedir. Yapılan bu düzenlemeye göre ittifak yapan partiler bir ittifak unvanı seçebilecekler ve bu unvan oy pusulasında ittifakı oluşturan partilerin logolarının üzerinde yer alan dikdörtgende belirtilmektedir. İttifakın bir unvan belirlemesi hâlinde ilgili dikdörtgende sadece "ITTIIFAK" ibaresine yer verilmekte, birden fazla ittifakın olması ve unvan belirlememeleri hâlinde ise ittifaklar başvuru sırasına göre numaralandırılmaktadır.

Seçim ittifaklarına imkân veren düzenlemeler arasındaki ön önemlisi seçim barajına ilişkin düzenlemelerdir. Milletvekili Seçimi Kanununun 33. maddesinin 1. fikrasına eklenen cümleye göre "Seçim ittifakı yapılması halinde, yüzde onluk barajın hesaplan-

72 Gürsel, “Türkiye İçin Yeni Seçim Sistemi Önerisi”, s.16. 
masında ittifak yapan siyasi partilerin aldıkları geçerli oyların toplamı esas alınır ve bu siyasi partiler için ayrıca baraj hesaplaması yapılmaz. Bir siyasi parti listesinde yer almış, bağımsız adayların seçilebilmesi de listesinde yer aldı̆̆ siyasi partinin ülke genelinde ve ara seçimlerde seçim yapılan çevrelerin tümünde yüzde onluk barajı aşması ile mümkündür”. Bu düzenleme ile herhangi bir seçim ittifakına dâhil olan bir siyasî parti ülke genelinde uygulanan \%10'luk seçim barajını geçememiş olsa dahi ittifakın toplamının aldığı oyların barajı geçmesi hâlinde barajı geçmiş sayılacaktır.

24 Haziran 2018 tarihinde yapılan seçimlerde seçim ittifakı ilk defa uygulanmıştır. 24 Haziran seçimlerine iki farklı ittifak katılmıştır: Cumhur İttifakı ve Millet İttifakı. Millet İttifakını oluşturan üç partinin içerisinde yer alan İyi Parti, \%9,96 oranında oy almasına karşılık, dâhil olduğu ittifakın toplam oyu ülke barajı olan \%10'u geçtiği için barajı geçmiş sayılmış ve TBMM'de 43 sandalye kazanmıştır. Bu sonuç da göstermektedir ki 24 Haziran 2018 seçimlerinde seçim ittifakı yapan partiler bakımından ülke seçim barajı fiilen sıfırlanmıştır.

Seçim ittifakı yapan partilerin tamamının toplam oyunun her zaman \%10’luk ülke barajını geçebilmesi mümkün olmayabilir. Fakat seçim ittifakı, ittifaka katılan partiler bakımından fiilen seçim barajını kaldırma imkanını sağladığı için seçim barajının işlevini yitirdiği sonucuna ulaşmak gerekmektedir.

\section{Sonuç}

12 Eylül 1980 tarihinde gerçekleşen askerî darbe, kendisinden önceki 1961 Anayasası döneminde ortaya çıkan hükümet istikrarsızlıklarını gidermek için temsil adaletinden taviz vermiş ve \%10'luk ülke seçim barajını kabul etmiştir. 12 Eylül 1980 askerî darbesinin siyaset mühendisliğinin bir neticesi olarak ortaya çıkan ülke seçim barajı uygulaması, yönetim istikrarını sağlama amacını gerçekleştirmede başarısız olmuştur. Özellikle 1990’lı yıllar boyunca kurulan koalisyon hükümetleri bu başarısızlığın açık bir delilidir. Benzer bir şekilde ülke seçim barajı uygulaması ile siyasî partilerin ve seçime giren partilerin sayısının azaltılması amacı da gerçekleşmemiştir.

Etnik/bölgesel partilerin kurulmasının engellenmesi amacını yerine getirmekte başarısız olan ülke seçim barajı uygulaması, etnik/bölgesel partilerin parlamentoya girebilmelerini önemli ölçüde engellemiş olsa da bu engel seçim ittifakları ve bağımsız aday göstermek suretiyle aşılmıştır. Son yapılan her iki genel seçimde de etnik/bölgesel bir siyasî partinin ülke seçim barajını aşmayı başararak parlamentoda temsil imkânı bulması bu amacın yerine getirilmesinin artık söz konusu olamayabileceğini göstermektedir.

Seçmen davranışlarını büyük ölçüde etkileyen ve seçmenleri ilk tercihleri olan siyasî partileri desteklemek yerine genellikle ikinci tercihlerine yönlendiren ülke seçim barajı uygulaması, temsil adaletinin sağlanarak millî iradenin yasama faaliyetlerine daha çok yansımasını engellemektedir.

16 Nisan 2017 tarihinde yapılan halkoylaması ile kabul edilen anayasa değişikliğinin yönetimde istikrarı garanti eden yeni bir hükümet sistemine geçişi ifade ettiği 
yönündeki vurgu temsil adaletine ağırlık verilmesi gerekliliğini kaçınılmaz hâle getirmiştir. Bu nedenle temsil adaletinin tam manada sağlanabilmesi için sıfır barajlı nisbî (orantılı) temsil sistemi tercih edilmelidir. Kuvvetler ayrılığının benimsendiği ve yürütmeyi Cumhurbaşkanının tek başına oluşturduğu gerçeğinden hareketle ülke barajının anlamın yitirdiğini söylemek gerekmektedir. Birçok ülkeyle beraber Türkiye'de de artık oyların hesaplanmasına ilişkin olarak kullanılan d'Hondt sistemi üzerinde çok fazla tartışma yaşanmıyor olduğu ve d'Hondt sisteminin büyük partilere avantaj sağladığı düşünüldügünde sıfır barajdan kaynaklı olarak ortaya çıkabilecek parçalı bir parlamentonun oluşması ihtimali nispeten azalacaktır. Ayrıca seçim sistemi üzerinde yapılan siyasî hesapların beklenenin aksine sonuçlar doğurduğ $\mathrm{u}^{73} \mathrm{da}$ göz önüne alınmalı ve temsil adaletinin sağlanması için seçim barajı kaldırılmalıdır. Her ne kadar seçim barajının yapılacak ilk düzenleme ile sıfırlanması gerçekçi gözükmese de kanun koyucunun kamuoyunun taleplerini dikkate almak suretiyle bu adımı atması mümkündür. Bununla birlikte ülke seçim barajı oranının azaltılması hâlinde ise, tek başına barajın düşürülmesi bugün seçim sisteminden kaynaklı olarak yaşanan sorunları çözmeyecektir. Milletvekili adaylarının belirli bir kısmının ön seçimle belirlenmediği, seçmenlere milletvekili adaylarından istediklerini seçme imkânının verilmediği ve milletvekillerinin illere dağılımında her ile öncelikle bir milletvekili tahsisi nedeniyle bazı illerin daha fazla temsil edildiği bir seçim sisteminde ülke seçim barajının düşürülmesi önemli ve gerekli, fakat tek başına yeterli bir adım değildir.

\section{Kaynakça}

Anayasa Mahkemesi, 18 Kasım 1995 tarih ve E. 1995/54, K. 1995/59 sayılı Karar, RG, 21 Kasim 1995, Say1 22470.

Bağce, H. Emre. “Türkiye'de Siyasi Partiler ve Seçimler: 1946-2015”. Edip Asaf Bekaroğlu (der.). Türkiye'de Siyasi Partiler ve Seçim Kampanyaları: Araftaki Seçim - 7 Haziran 2015. İstanbul: Vadi Yayınları, 2015.

Bahçeci, Barış. "1982 Anayasası Döneminde Çoğulcu Demokrasi Açısından Milletvekili Seçimi Hukukunda Karşılaşılan Sorunlar”. Ankara Üniversitesi Hukuk Fakültesi Dergisi. 54 (2005): 365-396.

Bulut, Nihat. “Temsilde Adalet - Yönetimde İstikrar İkilemi Bağlamında 12 Haziran 2011 Seçimleri”. Erzincan Üniversitesi Hukuk Fakültesi Dergisi. 14/III-IV (2010): $1-18$.

Danışma Meclisi Tutanak Dergisi. C.1. 23.10.1981 tarihli oturum.

Danışma Meclisi Tutanak Dergisi. C.17. 25.4.1983 tarihli oturum.

Gözler, Kemal. Anayasa Hukukunun Genel Teorisi. Cilt 1. Bursa: Ekin Basım Yayın Dağıtım, 2011.

Gürsel, Seyfettin. “Türkiye İçin Yeni Seçim Sistemi Önerisi”, Rapor, İstanbul: Bahçeşehir Üniversitesi Ekonomik ve Toplumsal Araştırmalar Merkezi, Ocak 2013.

Kesgin, Bedrettin. Siyaset Bilimi ve Kamu Yönetimi, İstanbul: Aç1lım Yayınları, 2014.

73 Yüzbaşığlu, “Türkiye’de Uygulanan Seçim Sistemleri”, s.145. 
Oder, Burak. “1983’ten Bu Yana Seçim Sisteminde Yaşanan Değişiklikler ve 24 Aralık 1995 Seçimi Sonuçlarının Çeşitli Varsayımlarla Değerlendirilmesi”. İstanbul Üniversitesi Hukuk Fakültesi Mecmuası. 55/IV (1997): 85-107.

Özbudun, Ergun. "Seçim Sistemleri ve Türkiye”. Ankara Üniversitesi Hukuk Fakültesi Dergisi. 44/I (1995): s. 521-539.

Özbudun, Ergun. Türk Anayasa Hukuku. 15. bs. Ankara: Yetkin Yayınları, 2014.

Sabuncu, Yavuz. "Seçim Barajları ve Siyasal Sonuçları”. Anayasa Yargısı Dergisi. 23 (2006): 191-197.

Seçim Sistemi ve Siyasî Partiler Araştırması, Cilt II, Ana Rapor. TÜSİAD. İstanbul: 2001.

Tahmazoğlu Üzeltürk, Sultan. "Türk Anayasa Mahkemesi Kararlarında Seçim Sistemleri”. Anayasa Yargısı Dergisi. 23 (2006): 237-278.

Tanör, Bülent ve Necmi Yüzbaşıŏlu. 1982 Anayasasına Göre Türk Anayasa Hukuku, 16. bs. İstanbul: Beta Yayınları, 2016.

TBMM Anayasa Komisyonu Raporu. Çevrimiçi: https://anayasa.tbmm.gov.tr/ docs/1982/1982-19/19-sirasayisi.pdf, 29 Eylül 2017.

Teziç, Erdoğan. Anayasa Hukuku. 20. bs. İstanbul: Beta Basım Yayım Dağıtım, 2016.

Türk, Hikmet Sami. "Seçim, Seçim Sistemleri ve Anayasal Tercih”. Anayasa Yargısı Dergisi, 23 (2006): 75-113.

Yargıtay Cumhuriyet Başsavcılığı. "Faaliyette Olan Siyasi Partiler”. Çevrimiçi: http://www.yargitaycb.gov.tr/sayfa/faaliyette-olan-siyasi-partiler/documents/ Spartiler12092017.pdf, 17 Eylül 2017.

Yüzbaşığlu, Necmi. “Türkiye’de Uygulanan Seçim Sistemleri ve Bunlara İlişkin Anayasa Mahkemesi Kararlarına Göre Nasıl Bir Seçim Sistemi”. İstanbul Üniversitesi Hukuk Fakültesi Mecmuası. 55/I-II (1995-1996): 103-150. 


\title{
Electoral Threshold Implementation in Turkey within the Framework of Two Principles: Justice in Representation and Stability in Governing
}

\author{
BATUHAN USTABULUT
}

\begin{abstract}
According to Article 67 of the 1982 Constitution, the election laws must be regulated in a manner that accommodates the principles of justice in representation and stability in administration. These principles work in the opposite direction. Therefore, electoral systems have preferred one of these two principles while the other compromises from the first. First of all, goals of election threshold implementation and to what extent these goals are achieved will be $d w e l l e d$ on this article. Then the constitutional amendment in the referendum held on 2017 how would affect these two functions, and whether the $10 \%$ electoral threshold would contribute to ensuring justice in representation are evaluated. It also examines the election alliances, which were adopted before the 24 June 2018 elections, how had an impact on the election threshold. It is concluded that the goals wanted with the election threshold are not fulfilled to a great extent and that the lack of the representation justice has negative effects on the voting activities of the voters and the election alliances have the potential to lift the election threshold.
\end{abstract}

Keywords: Electoral systems, Justice in representation, Stability in administration, Election threshold. 